\title{
PROPIEDADES FORMALES DE CODIFICACIÓN DE PARTICIPANTES Y CAMBIOS INDUCIDOS POR CONTACTO EN EL ESPAÑOL HABLADO POR LOS MALECUS
}

Carlos Sánchez Avendaño

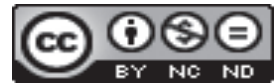

Esta obra está bajo una licencia Creative Commons 



\title{
PROPIEDADES FORMALES DE CODIFICACIÓN DE PARTICIPANTES Y CAMBIOS INDUCIDOS POR CONTACTO EN EL ESPAÑOL HABLADO POR LOS MALECUS
}

\section{CODING'S FORMAL PROPERTIES OF PARTICIPANTS AND CHANGES INDUCED BY CONTACT IN THE SPANISH SPOKEN BY MALECUS}

\author{
Carlos Sánchez Avendaño
}

\begin{abstract}
RESUMEN
En este artículo se analizan, desde la perspectiva de la lingüística de contacto, los fenómenos morfosintácticos de variación en el español malecu relacionados con las propiedades formales de codificación gramatical de los participantes y presuntamente inducidos por el contacto entre el idioma malecu y el español: la neutralización de la categoría verbal de número en la tercera persona, la mayor frecuencia de la concordancia ad sensum con el sustantivo colectivo 'gente' como sujeto en una misma cláusula, la concordancia verbal con el argumento que codifica el participante experimentador en las cláusulas con verbos de dativo, la neutralización de la categoría de número en los clíticos de objeto indirecto y la codificación de participantes benefactivos/destinatarios/ receptores mediante una frase preposicional con 'para'.

Palabras clave: malecu, español de contacto, cambio inducido por contacto, relaciones gramaticales, concordancia verbal.
\end{abstract}

\begin{abstract}
In this article we analyze, from the perspective of contact linguistics, the morpho-syntactic phenomena of variation in the Spanish spoken by the Malecu related to formal properties of grammatical codification of participants and allegedly induced by contact between the Malecu language and Spanish: the neutralization of the verbal category of number in the third person, the bigger frequency of ad sensum verb agreement with the collective noun 'gente' (people) as subject of the same clause, the verbal agreement with the argument which codifies the experiencer participant in the clauses with dative verbs, the neutralization of number category in the indirect object clitics, and the codification of benefactive/addressee/recipient participants through a prepositional phrase with 'para' (for).

Key words: malecu, contact Spanish, contact-induced change, grammatical relations, verb agreement.
\end{abstract}

Dr. Carlos Sánchez Avendaño. Universidad de Costa Rica. Profesor de la Escuela de Filología, Lingüística y Literatura. Costa Rica.

Correo electrónico: tocumarama@yahoo.es

Recepción: 03- 04- 2015

Aceptación: 15- 04- 2015 


\section{Introducción}

Los malecus (denominados habitualmente "guatusos" en los documentos históricos, crónicas de viaje de los siglos XIX y XX, y en múltiples trabajos académicos de corte lingüístico y antropológico) constituyen uno de los pueblos originarios del territorio costarricense. La mayoría de la población (unos 500 individuos) reside en el cantón de Guatuso, provincia de Alajuela, actualmente en tres comunidades (denominadas "palenques"): El Sol, Tonjibe y Margarita.

En el presente, de acuerdo con el diagnóstico más reciente (Sánchez, 2011), su lengua autóctona se encuentra en un estadio intermedio del proceso de desplazamiento, el cual se manifiesta en el cese de la transmisión intergeneracional del idioma, la reducción de sus dominios de uso y un heterogéneo continuum de competencia bilingüe.

En cuanto al dominio de la lengua española, cabe destacar que en la actualidad (y la tendencia se reporta desde los trabajos de Constenla, 1975; 1988) no quedan personas monolingües en malecu. Los ancianos (personas mayores de 65 años) y los adultos mayores (personas de más de 50 años aproximadamente), de acuerdo con nuestra clasificación ad hoc (Sánchez, 2011), son bilingües sucesivos, con el malecu como primera lengua (y claramente dominante en el caso de las personas mayores de 70 años en Margarita y mayores de 60 en Tonjibe, aunque la situación puede variar mucho dependiendo de la biografía de cada individuo). En las personas menores de 50 años, conforme decrece la edad, se encuentra, progresivamente, más bilingüismo equilibrado malecu-español y bilingüismo con el español como lengua dominante, hasta llegar al semilingüismo en malecu, el bilingüismo predominantemente receptivo en malecu y el monolingüismo en español.

El español fue adquirido por las personas ancianas o adultas mayores normalmente de manera natural (con o sin ayuda de la escolarización) y en muchos casos en edad relativamente tardía (después de los 7 años lo más pronto, en el caso de los que asistieron a la escuela, o incluso en la adolescencia o la juventud temprana). Dependiendo del individuo, entonces, en esta generación se encuentran rasgos lingüísticos de interlengua, con fosilizaciones y con mucha variación idiosincrática, motivada por la interferencia de la lengua materna o por acción normal del proceso de adquisición de una segunda lengua (Sánchez, 2016).

Además, se pueden reconocer algunos fenómenos lingüísticos con continuidad intergeneracional, los cuales, aunque muestren tendencia hacia la disminución de la frecuencia de aparición conforme se pasa de la generación de los abuelos a la generación de los nietos (sea por presión normativa de la escuela o porque el influjo directo o indirecto de la lengua malecu va mermando, entre otras posibles razones), aún están vigentes en mayor o menor medida, no solo con toda claridad en el habla de los bilingües simétricos (sucesivos y simultáneos), sino incluso muchas veces también en el habla de los bilingües asimétricos con el español como lengua dominante que han crecido con el malecu como lengua presente en su cotidianidad y hasta en los jóvenes y niños (cuasi)monolingües en español. ${ }^{1}$

De los rasgos fonéticos, léxicos y morfosintácticos más destacables del español hablado por los malecus en la actualidad dimos cuenta en Sánchez (2016). En cuanto al análisis detallado de fenómenos morfosintácticos, nos ocupamos de la reestructuración del sistema de clíticos de objeto directo en Sánchez (2015). En el presente trabajo estudiaremos a profundidad, desde la perspectiva de la lingüística de contacto, otros fenómenos con vigencia intergeneracional, todos ellos vinculados con las propiedades formales de codificación gramatical de los participantes. 
Como se verá, resulta indispensable, para llevar a cabo esta labor, contrastar las gramáticas del español y del malecu, indagar sobre los cambios y la inestabilidad del subsistema morfosintáctico particular del español que se esté analizando, y recurrir como parámetro de comparación -así como de posible fuente del cambio- a las variedades del español costarricense sin influjo evidente de una lengua indoamericana.

En este trabajo, a excepción de la concordancia ad sensum con 'gente', prescindimos del cálculo de la frecuencia de los fenómenos en discusión por un motivo: muchos de ellos están infrarrepresentados en el corpus discursivo con el que contamos (unas veinte horas y media de grabación sobre el tema del desplazamiento de la cultura tradicional y la lengua vernácula). ${ }^{2}$ Aunque este corpus nos permite cuantificar la aparición de los rasgos por grupos generacionales y comunidades, tras varios años de interacción constante con miembros del pueblo malecu, estamos seguros de que en la conversación espontánea cotidiana los fenómenos a los que nos referiremos aparecen con relativa frecuencia y ciertamente no son idiolectales. Todo lo contrario: ocurren con alguna regularidad en muchos hablantes.

Por ende, únicamente tratamos los fenómenos que hemos detectado en varios hablantes y en diversos momentos. Los ejemplos que consignamos provienen de varias fuentes: el corpus discursivo ya mencionado, anotaciones de conversaciones espontáneas, y grabaciones de traducciones al español de la tradición oral malecu.

\section{La lingüística de contacto y los cambios indirectos inducidos por contacto}

La lingüística de contacto se interesa en todos los fenómenos idiomáticos resultantes del contacto entre dos o más grupos humanos con sus respectivos y distintos idiomas: los repertorios multilingües en el individuo, la adquisición y retención de dichos repertorios, el multilingüismo social, el cambio de códigos en la interacción, los préstamos, la convergencia de estructuras y el surgimiento de variedades lingüísticas nuevas (Matras, 2009).

Una parcela particularmente cosechada en este amplio espectro es el estudio de las consecuencias estructurales del contacto (o cambios estructurales producidos por contacto), tomando en cuenta factores psicolingüísticos y sociolingüísticos, pero centrándose sobre todo en las lenguas como sistemas. Dentro de este interés, se plantea que nos encontramos esencialmente ante dos tipos de fenómenos: el préstamo y la transferencia lingüística (Thomason, 2001).

Se insiste en la teorización contemporánea acerca del contacto de lenguas en la necesidad de diferenciar entre la importación de material lingüístico (una palabra, un afijo o un conector discursivo, por ejemplo) y la replicación de patrones estructurales. En el primer caso, el más evidente del contacto, los hablantes toman un elemento de la lengua A y lo emplean en su discurso en el idioma B. En el segundo caso, se trata más de una característica estructural de la lengua A que de alguna manera funciona como modelo para el cambio (de significado, de distribución, de comportamiento) o la gramaticalización de otra estructura en la lengua B (Matras, 2009).

A este respecto -y refiriéndose en particular al contacto entre el español y las lenguas amerindias-, Palacios $(2008 ; 2011 ; 2013)$ señala que resulta imperativo no perder de vista que la influencia de la lengua A (el malecu, en nuestro caso) puede consistir en incentivar un cambio estructural incipiente ya presente en la lengua A (el español, en nuestro caso) más 
que en la importación de una estructura como tal (de ahí el nombre de "cambios indirectos por convergencia" o "cambios indirectos inducidos por contacto"), en un proceso complejo relacionado con las estrategias comunicativas de que dispone el hablante. Así las cosas, en este trabajo asumimos la posición manifestada por Palacios $(2011$, p. 19) en lo relativo a las variedades idiomáticas surgidas por contacto:

\begin{abstract}
[S]i partimos de una perspectiva teórica que concibe las gramáticas de las lenguas (y de las variedades de las lenguas) como sistemas dinámicos donde los hablantes categorizan modos de representar la realidad, podemos afirmar que, en las zonas de contacto lingüístico, la coexistencia de lenguas puede conllevar distintos modos o sistemas de categorización que podrían manifestarse en variaciones lingüísticas significativas en las variedades de lengua que usan los hablantes de esas zonas bilingües. Si esto es así, entenderíamos que en estas variaciones subyacen procesos cognitivos distintos, que conllevarían cambios de significado, adaptaciones, mezclas, reorganizaciones de sistemas o subsistemas lingüísticos, etc. En un proceso distinto, de difusión de esas variaciones, esto es, de los cambios inducidos por contacto, la presión de la norma (social o institucional) puede frenar considerablemente su expansión, ya que estos cambios están ligados, en muchos casos, a una categorización social que los sitúa en una esfera poco prestigiosa e incluso marginal.
\end{abstract}

Con respecto a los cambios indirectos inducidos por contacto, Palacios (2011) agrega que el contacto actúa como factor exógeno al sistema linguiístico para promover el cambio, pero en realidad aprovecha la inestabilidad, la variabilidad o las tendencias internas del sistema mismo:

\begin{abstract}
Entiendo los cambios indirectos inducidos por contacto como cambios multicausales compatibles con las tendencias internas del sistema. Este tipo de cambio ha sido motivado tanto interna (evolución interna de la lengua) como externamente (por el contacto con otras lenguas). No supone importación de material ajeno, ya que el cambio lingüístico se produce a partir de una variación ya existente en la lengua. Así, mediante la influencia indirecta de una lengua en contacto A surgen variaciones gramaticales muy significativas, generalmente en el registro oral coloquial de la lengua B, que aprovechan la propia evolución interna de esa lengua B para hacer aflorar estrategias gramaticales cuya funcionalidad comunicativa obedece a procesos cognitivos de la lengua A de contacto. (Palacios, 2011, pp. 25-26)
\end{abstract}

De acuerdo con Palacios $(2011 ; 2013)$, los subsistemas morfosintácticos del español inestables, con notable variabilidad o en proceso de cambio lingüístico son particularmente propensos al cambio inducido por contacto, sea porque este se encuentre ya en marcha y se acelere por efecto del contacto, porque se desdibujen las restricciones de tipo lingüístico que limitan su extensión, porque se produzca una restructuración del subsistema gramatical completo o porque los repertorios idiomáticos disponibles adquieran nuevos valores semánticos.

Como tales cambios son acelerados precisamente por la reinterpretación y reorganización de los sistemas gramaticales del español por influjo de la organización lingüístico-cognitiva de la lengua amerindia de contacto, se requiere encontrar la motivación estructural-cognitiva en la lengua de contacto que promueva el cambio e incluso que lo dirija en una dirección distinta a la esperable por acción de las tendencias universales, si es el caso. Asimismo, se torna necesario indagar en el proceso de evolución del fenómeno y de variación interna en español, con el fin de explicar de qué manera actúa la lengua de contacto en la promoción del cambio (Palacios, 2011; 2013).

En suma, el tipo de consecuencia del contacto de lenguas que nos interesa en el presente trabajo es el que se ha denominado "convergencia", en el sentido de "generalización o intensificación de ingredientes que ya existen, en distinto grado, en las dos lenguas afectadas, cuyas gramáticas al cabo de un tiempo de contacto intenso alcanzan cierto sincretismo" (Conde, 2007, p. 241).

Cabe destacar que asumimos una perspectiva comparativa con el propósito de poder llevar a cabo nuestra descripción. Nuestros puntos de referencia serán, en primer lugar, las 
variedades del español habladas en el territorio costarricense sin contacto con una lengua amerindia, tal y como han sido descritas o documentadas, de forma global, en Agüero (2009), Arroyo (1971) y Quesada $(1990 ; 1991 ; 2009 ; 2010)$ y en artículos monográficos que citaremos oportunamente; en segundo lugar, recurriremos a descripciones y datos de otras variedades de español con o sin influjo de una lengua indoamericana.

\section{Codificación de participantes, relaciones gramaticales y concordancia verbal en español y en malecu}

Los fenómenos de variación inducidos por contacto en el español malecu que analizaremos en los apartados siguientes se vinculan todos con la codificación gramatical de los participantes del evento (o, como también se les denomina, roles semánticos) por medio de propiedades morfosintácticas. Por este motivo, de manera muy sucinta hemos de referirnos a los conceptos fundamentales que permitirán construir nuestra argumentación.

Siguiendo a Halliday (2004), podemos pensar que las cláusulas, en tanto representación de la experiencia, muestran una configuración de tres componentes: el evento (o proceso, en la terminología de este lingüista) que se desarrolla en el tiempo, los participantes involucrados en ese evento y las circunstancias en las que tiene lugar el evento. Típicamente, el evento se codifica formalmente mediante un grupo verbal; los participantes, por medio de grupos nominales; y las circunstancias, como grupos adverbiales y frases aposicionales. Para nuestro análisis, la categoría fundamental será la de los participantes. ${ }^{3}$

Suelen proponerse algunos tipos básicos, en un continuum semántico de naturaleza no discreta. Así, por ejemplo, se habla del "agente" o "actor", dependiendo de la escuela funcionalista, para referirse al participante habitualmente animado que actúa de forma deliberada y desencadena el evento, el realizador de la acción o provocador del cambio, mientras que el "paciente" o "meta" alude al participante que sufre un cambio de estado como consecuencia del evento o al participante hacia el que se extiende el proceso.

En función de las necesidades de nuestro análisis, hemos de recurrir a nombres ad hoc para referirnos a otros tipos de participantes. Por ello, al tratar la concordancia con verbos de dativo, hablaremos de participantes "experimentadores" (etiqueta con la que traducimos el tipo "Senser" de Halliday, 2004, el cual consiste en un participante que siente, piensa, percibe o desea) y de participantes "causantes" (correspondiente al tipo "Phenomenon" de Halliday, 2004, el cual se refiere a lo pensado, sentido, deseado o percibido).

Asimismo, aludiremos de manera algo vaga mediante las etiquetas "benefactivo", "beneficiario", "destinatario" o "receptor" al participante que, de acuerdo tanto con Halliday (2004) como con Givón (2001), resulta beneficiado por el evento. Cuando el evento es de tipo verbal, siguiendo a Halliday (2004), existe un participante a quien se dirige lo que se dice y al que denominaremos "receptor o destinatario del evento verbal" (equivalente al "Receiver" de Halliday).

Situándonos ya más concretamente en la línea del funcionalismo tipológico de Givón (2001), se concibe que los participantes del evento se codifican mediante funciones gramaticales en la cláusula. Tales funciones, llamadas también relaciones gramaticales o argumentos, incluyen, como categorías centrales o nucleares (debido a las consecuencias gramaticales con las que se vinculan), el sujeto y el objeto directo en las lenguas nominativoacusativas, y el ergativo y el absolutivo en las lenguas ergativo-absolutivas. El objeto indirecto, según Givón, ocupa una posición de centralidad intermedia. Las denominadas “consecuencias 
gramaticales" tienen que ver, en gran medida, con propiedades formales como la concordancia verbal, el orden de los constituyentes y la morfología nominal. ${ }^{4}$

De forma muy simplificada, se puede decir que en las lenguas nominativo-acusativas, como el español, la principal consecuencia gramatical consiste en que el agente y el paciente de un verbo transitivo deben distinguirse mediante alguna propiedad formal. Por esta razón, en una cláusula activa, el agente se codifica como sujeto (o "nominativo") y el paciente se codifica como objeto directo (o "acusativo"). Por su parte, sea cual sea el participante, en una cláusula intransitiva el participante se codifica como sujeto. Las propiedades formales en español incluyen el que el verbo muestre concordancia morfológica con el sujeto y que el objeto directo se introduzca con la preposición 'a' (cuando se trata de humanos específicos, al menos). El participante beneficiario se codifica como objeto indirecto y se introduce con la preposición 'a' en todos los casos. Además, existe una serie de pronombres personales que distinguen estas categorías morfológicamente (por ejemplo, en la tercera persona singular masculina, 'él' es sujeto, 'lo' es objeto directo y 'le' es objeto indirecto, por lo menos en el sistema etimológico).

En las lenguas ergativo-absolutivas, como el malecu, el agente de una cláusula transitiva se distingue formalmente frente al paciente de una cláusula transitiva o el participante de una cláusula intransitiva. Esto es, se distingue formalmente entre el ergativo (el agente de la transitiva) frente al absolutivo (el paciente de una transitiva o el participante que aparezca en una intransitiva). Dicho en términos comparativos, el ergativo correspondería al sujeto de una cláusula transitiva, mientras que el absolutivo correspondería tanto al objeto directo de una cláusula transitiva como al sujeto de una intransitiva.

La propiedad formal básica de esta distinción en malecu consiste en la existencia de dos series de prefijos verbales: uno para la marcación del ergativo y otro para la marcación del absolutivo. El sistema es el siguiente (incluimos todos los alomorfos, pero no entraremos en detalle en cuanto al condicionamiento fonológico que regula la aparición de uno u otro):

Cuadro 1. Prefijos verbales de ergativo y absolutivo en malecu (Basado en Constenla, 1998)

\begin{tabular}{|l|l|l|l|}
\hline \multicolumn{2}{|c|}{} & Ergativo & Absolutivo \\
\hline Primera persona & Exclusiva & rra- & na- \\
\cline { 2 - 4 } & Inclusiva & ri- & ma- \\
\hline Segunda persona & & $\begin{array}{l}\text { rrifa- } \sim \text { rrfa- } \sim \text { rrif- } \sim \text { rrf- } \\
\sim \text { rrip- } \sim \text { rrp- }\end{array}$ & mi- $\sim$ ma- \\
\hline Tercera persona & & rri- & i- a- $\varnothing$ \\
\hline
\end{tabular}

A modo de ejemplo, si comparamos una cláusula transitiva en español como 'él lo golpeó' con las intransitivas 'él corrió' y 'él murió', notamos que se diferencia formalmente entre el sujeto ('él') y el objeto directo ('lo') de la transitiva, mientras que el participante en las intransitivas se codifica como sujeto ('él') independientemente de si es agente (como en 'él corrió') o paciente (como en 'él murió'). En malecu, las respectivas construcciones serían irricorróye 'él lo golpeó, ióje ‘él corrió' e itáte 'él murió', en las que -como se ve- el participante de ambas intransitivas se codifica mediante el mismo prefijo ( $i-$ ) que el objeto directo de la transitiva, no como sujeto, que es lo que ocurre en español.

Si bien difieren en sus sistemas de marcación de casos (nominativo en español, ergativo en malecu), la gramática de ambas lenguas comparte una propiedad formal fundamental: el verbo concuerda mediante algún afijo (un sufijo en el caso del español y un prefijo en el caso del malecu) con uno o dos de los argumentos centrales: en español, el verbo concuerda con 
el sujeto; en malecu, el verbo concuerda tanto con el ergativo como con el absolutivo. Esta divergencia/convergencia está en la raíz de algunos de los cambios inducidos por contacto que se atestiguan en el español malecu, como procuraremos mostrar en las páginas sucesivas.

Lo que hemos expuesto hasta el momento solo tiene como propósito sentar el marco conceptual general de las propiedades formales vinculadas con la codificación de los participantes del evento mediante los argumentos o relaciones gramaticales. Los demás detalles pertinentes acerca de la gramática tanto del malecu como del español se comentarán, conforme resulte pertinente, en las distintas secciones a continuación.

\section{Cambios inducidos por contacto en el español malecu en relación con las propiedades formales de codificación de los participantes}

En este apartado nos detendremos en el examen pormenorizado, desde la perspectiva de la lingüística de contacto expuesta, de tres fenómenos de concordancia verbal en relación con el argumento que se interpreta como sujeto en el español hablado por los malecus. Luego, describiremos algunos fenómenos de cambio en relación con los objetos directo e indirecto.

Para cada fenómeno, primeramente consignamos algunos ejemplos y nos referimos a su vigencia intergeneracional. En segundo lugar, contrastamos el fenómeno en el español malecu con respecto al español costarricense no malecu (y a veces también en relación con otras variedades del español, con o sin influjo de una lengua amerindia) en términos tanto cualitativos (en qué medida difieren los patrones gramaticales entre las variedades comparadas) como cuantitativos (en qué medida se trata de los mismos patrones pero de frecuencias de aparición distintas). En tercer lugar, nos referimos a la variación y al cambio en proceso o en ciernes en el ámbito morfosintáctico del español descrito en cada caso, como evidencia de que el contacto de lenguas ha promovido el ir más lejos en el desarrollo de este. Finalmente, examinamos la gramática del malecu con el propósito de argumentar a favor de la interpretación del posible origen del fenómeno: el cambio inducido por contacto.

\subsection{El argumento sujeto y la concordancia verbal}

\subsubsection{La neutralización de la categoría verbal de número en la tercera persona}

Como se detalla en Sánchez (2016), las discordancias entre el sujeto y el verbo regido por este son múltiples en el español de los ancianos de Margarita y Tonjibe. En su habla se hallan verbos con flexión en tercera persona singular y pronombre de sujeto en primera persona singular (como en 1.), verbos con flexión en tercera persona singular y pronombre de sujeto en primera persona plural (como en 2.), verbos con flexión en tercera persona singular y pronombre de sujeto en tercera persona plural (como en 3.), verbos con flexión en segunda persona singular 'usted' y pronombre de sujeto en segunda persona plural 'ustedes' (como en 4.):

\section{1. yo escucha; yo nació aquí; yo ha matado}

2. nosotros es malecu

3. maestros no está enseñando en eso; ellos no creció aquí en mi casa; lo que ha hecho aquí estos paisanos míos; cuando viene esos gringos ojos celestes.

4. solo ustedes habla en en el español 
En los adultos mayores de Margarita con bilingüismo equilibrado, estas discordancias se limitan, principalmente, a la neutralización entre la tercera persona plural y la tercera persona singular (como en 5.). Lo mismo ocurre en el habla de los adultos y adultos jóvenes de las tres comunidades (como en 6.), así como en el habla de los jóvenes de los tres poblados (como en 7.)

\section{5. los guaimíes sí mantiene su cultura; lo vio los chiquitos}

6. ellos no le entiende a mi mamá; cuando dice los muchachos; quiere que nuestros hijos se supere

\section{7. no le salía las palabras a ella; muchas personas dice}

Esta neutralización ocurre también en cláusulas de relativo, cuando el pronombre relativo 'que' es correferencial con un grupo nominal antecedente plural, tanto en el habla de los adultos como en la de los jóvenes (como en 8.):

\section{8. hay palabras que que ya se extinguió; hay varias cosas que que no va ir en el libro}

En las variedades del español sin contacto con otras lenguas habladas en Costa Rica, los tipos de discordancia formal sujeto-verbo que se han reportado únicamente tienen que ver con sustantivos de sentido colectivo (Sánchez, 2007), con grupos nominales del tipo 'una gran cantidad de personas' (Agüero, 2009; Sánchez, 2007), en oraciones pasivas con 'se' y en impersonales con 'se' (Agüero, 2009), y casos que Jara (2008) estudia como concordancias motivadas pragmática y no morfosintácticamente (y que incluyen algunas de las categorías anteriores), como en 'se detuvieron a tres personas' y 'en ningún momento se hablaron de comisiones'. Si bien en nuestro corpus de español malecu figura la discordancia en impersonales con 'se' (por ejemplo, 'varios lugares donde se castigaban a la gente por irrespeto a las leyes malecu'), las que nos conciernen aquí no son de este tipo.

Las discordancias en las que el verbo se conjuga en tercera persona singular mientras el sujeto es de primera persona o de tercera persona plural se registran casi todas en el corpus de ancianos y personas mayores. En el discurso de los individuos de la segunda y la tercera generación únicamente se presenta la discordancia del verbo conjugado en tercera persona singular cuando el sujeto es de tercera persona plural. Si bien en los ancianos las discordancias pueden ser atribuibles al proceso de adquisición del español como segunda lengua en edad tardía (lo cual explica la gran cantidad de ejemplos y la inestabilidad del sistema, el cual abarca discordancias con otras personas), en las demás generaciones (bilingües simétricos o con el español como idioma dominante) la neutralización a favor de la conjugación en tercera persona singular indica que esta parece ser la única solución de reestructuración motivada por algo más que el proceso de adquisición.

Partiendo de la hipótesis planteada por Palacios (2011; 2013), se podría pensar que la dirección de la simplificación del sistema de concordancia sujeto-verbo en el español malecu en la cual la distinción entre singular y plural se neutraliza a favor de la marcación en singular se asocia con el cambio inducido por el contacto prolongado e intenso con la lengua malecu.

Como ya se indicó, el idioma malecu codifica formalmente los participantes argumentales nucleares del evento por medio de prefijos verbales en los que el caso (la oposición entre ergativo y absolutivo) y la persona (primera exclusiva e inclusiva, segunda y tercera) son las nociones gramaticalizadas, mientras que la categoría de número no se codifica.

La codificación de la distinción entre singular y plural se lleva a cabo por medio del marcador de plural maráma, el cual es independiente de este subsistema morfosintáctico de 
prefijos verbales, pues se puede posponer tanto a bases nominales y pronominales como a bases verbales. Esta distinción, sin embargo, es marginal en la lengua, ya que la inclusión "obligatoria" de maráma muchas veces depende de que no existan indicios morfosintácticos o discursivos (o incluso contextuales) de la noción de pluralidad.

Además de lo señalado, hay que agregar que, en el caso de la primera persona, existen pronombres personales correferenciales a los prefijos que sí gramaticalizan la distinción de número: ton (y su alomorfo to) 'primera persona singular', toí ( tói) 'primera persona plural exclusiva', tótiquí ( tótic) 'primera persona plural inclusiva', mientras que en la segunda persona se emplea una sola base pronominal pó (con los alomorfos pu y púo) 'segunda persona singular' a la que se pospone el marcador maráma para codificar la noción de 'segunda persona plural' (pó maráma). No existe en la lengua un pronombre de tercera persona, pero el demostrativo ní 'este' puede cumplir sus funciones. En tal caso, actúa de la misma manera que el pronombre de segunda persona: ní 'él, ella, este, esta', ní maráma 'ellos, ellas, estos, estas' (Constenla, 1998).

No obstante, el empleo de tales pronombres, así como de los grupos nominales correferenciales a los prefijos de persona, parece depender de condicionamientos de tipo discursivos relacionados, por ejemplo, con el mantenimiento activo y la recuperación de las referencias discursivas en el texto (Krohn, 2012). Es decir, la categoría gramatical básica de marcación obligatoria en la lengua está constituida por los prefijos de persona, de modo que los demás elementos nominales y pronominales que sirvan para codificar los participantes del evento son más bien refuerzos y aclaradores de los prefijos (de ahí que Constenla, 1998, los denomine "detalladores").

A pesar de ello, parece que el comportamiento de la lengua en cuanto a la tercera persona es distinto. De acuerdo con la descripción de Constenla (1998), en tal caso es común que se elida el prefijo respectivo (o, dicho de otra manera, que se emplee el alomorfo $\varnothing$ ) en función de factores morfosintácticos (cuando el verbo va precedido inmediatamente por el grupo nominal correferencial) o bien fonológicos (cuando va seguido por algún prefijo de ergativo o el prefijo reflexivo/recíproco -todos ellos iniciados por consonante vibrante- y no va precedido por pausa). Esta elisión no ocurre con los prefijos de primera ni de segunda persona.

Es decir, -muy en consonancia con el universal lingüístico que predice que, en las lenguas que codifican la categoría de persona en el verbo, si alguna de ellas no se marca, la tendencia será a que sea la tercera (Croft, 1990) $)^{5}$ - el prefijo de tercera persona en malecu es el único susceptible de omitirse y ello ocurre con regularidad cuando el participante en el evento se codifica mediante un grupo nominal o pronombre, siempre y cuando este aparezca antepuesto (esto es, la elisión es posible en la referencia anafórica, como en 9.), puesto que, si se presenta pospuesto, el prefijo de tercera persona no se elide (esto es, la omisión no es posible en la referencia catafórica, como en 10.). Empero, es necesario destacar que, si bien no dudamos de que la elisión regular tenga lugar en el habla más tradicional descrita por Constenla (1998), no ocurre tan sistemáticamente en los datos que hemos recogido, por lo menos no mediante elicitación directa.

9. tafá tóye 'el jaguar se fue'6

tafá tó-ye

jaguar ir-MR

10. itóye táfa 'el jaguar se fue'

i-tó-ye táfa

3Ab-ir-MR jaguar 
En cualquier caso, lo importante de destacar aquí es que, cuando el contexto (la información extratextual) o el cotexto (la información textual) ayudan a identificar o a mantener activa la identidad del referente discursivo, no se incluye como parte de la cláusula el grupo nominal, sino tan solo el prefijo de tercera persona, y la noción de pluralidad -cuando se trata de tercera persona plural- se codificará mediante el marcador maráma. Ahora bien, como ya se aclaró, este marcador puede vincularse formalmente con el grupo nominal detallador (si este aparece, como en 11.) o con el verbo (si el grupo nominal no aparece, como en 12.): ${ }^{7}$

11. tafá maráma (i)tóye 'los jaguares se fueron';

tafá maráma (i)-tó-ye

jaguar Pl (3Ab)-ir-MR

ní maráma irricánhe érra 'ellos comieron iguana'

ní maráma i-rri-cánh-e érra

este Pl 3Ab-3Er-comer-MR iguana

12. itué maráme 'se fueron';

i-tué marám-e

3Ab-ir Pl-MR

errá rricánh maráme 'comieron iguana'

errá rri-cánh marám-e

iguana 3Erg-comer Pl-MR

¿En qué medida, entonces, podría pensarse que la gramática del malecu motiva la neutralización de la noción de plural en la tercera persona verbal en el español hablado por los malecus? Es decir, ¿por qué podría pensarse que estamos ante un cambio inducido por contacto? En primer lugar, debe tenerse en cuenta, precisamente, que la neutralización de la categoría de número se produce en tercera persona en los bilingües equilibrados o en los bilingües con el español como lengua dominante. Las discordancias en primera o tercera persona solo se encuentran sistemáticamente en el habla de los ancianos bilingües asimétricos con el malecu como idioma claramente dominante. Por este motivo, vemos que el habla de estos ancianos muestra las posibilidades máximas de neutralización a favor de la conjugación verbal en tercera persona singular en todas las personas gramaticales.

No obstante, este cambio en el habla de estos ancianos debe atribuirse al proceso de adquisición natural del español como segunda lengua en edad avanzada y no a interferencia de la gramática del malecu (pues en esta, como ya se ha expuesto, se marcan con claridad en el verbo las distintas personas gramaticales). Si la única discordancia con vigencia intergeneracional (sobre todo en la generación de los adultos, quienes suelen ser bilingües simétricos o al menos bilingües pasivos con distintos grados de posibilidades de producción) tiene lugar en la tercera persona, hemos de sospechar de un cambio inducido ahora sí por el contacto de las gramáticas de ambas lenguas.

En efecto, a la luz de todo lo indicado con respecto a la marcación de la noción de número en malecu, tómese en cuenta que, en todos los ejemplos documentados de español malecu en el que se produce la neutralización entre singular y plural en la tercera persona, el verbo va acompañado de un grupo nominal o pronombre que codifica el participante que funge como agente del evento verbal (gramaticalmente codificado como sujeto en español y como 
ergativo o absolutivo en malecu, según la cláusula). En tal grupo nominal o pronombre está incluida la marcación de la categoría de plural.

Así las cosas, la marcación del plural en el verbo resulta redundante, pero lo más importante es que de alguna manera se replica el patrón morfosintáctico del malecu: si el plural se codifica en el grupo nominal o el pronombre correferencial al afijo verbal de persona, entonces en el verbo no se marca esta categoría. Así como en malecu resultarían extrañas las construcciones en 13., en las cuales se codifica el plural mediante maráma tanto en el grupo nominal como en el verbo, así también en los ejemplos de discordancia en el español malecu documentados se hace descansar la codificación del plural en el grupo nominal o pronombre, mientras que en el verbo solamente se codifica la categoría de tercera persona y se elide el sufijo de plural - $n$ (-ron en pretérito simple), como en 14.:

\section{3. *tafá maráma itué maráme; tafá maráma i-tué marám-e jaguar Pl 3Ab-ir Pl-MR \\ * ní maráma érra irricánh maráme ní maráma érra i-rri-cánh marám-e este Pl iguana 3Ab-3Erg-comer Pl-MR}

14. los guaimíes sí mantiene su cultura; lo vio los chiquitos; ellos no le entiende a mi mamá; cuando dice los muchachos; que nuestros hijos se supere; muchas personas dice; venía dos borrachos; las señoras también habla bastante; ellos mantenía la lengua

\subsubsection{La concordancia ad sensum con el sustantivo colectivo 'gente'}

Un tipo particular de discordancia verbal en el español hablado por los malecus que merece tratarse por separado es la concordancia ad sensum con el sustantivo colectivo 'gente' (sustantivo morfológicamente singular pero con sentido plural y verbo morfológicamente en plural, frente a la que sería la concordancia morfológica: verbo morfológicamente en singular), uno de los rasgos de variación con mayor vigencia intergeneracional: se documenta en el habla de los ancianos (como en 15.), de los adultos (como en 16.) y de los jóvenes (como en 17.):

15. la gente no saben hacer eso; la gente cazan hoy en dí; otra gente vinieron; para que la gente digan; aquí pasaban mucha gente; la gente pero me aplaudieron

16. esta gente no le hablan; la mayoría de la gente adulta se han dedicado a enseñarle a ellos; la gente tienen que saberlo; ya mucha gente no van a comer eso

17. la gente saben de que sí; llegan gente que no son malecu; ahí es donde la gente se burlan de ellos; anduvieron gente del Ministerio de Cultura; la gente llegaron

El fenómeno está presente en el español costarricense sin influjo de una lengua de contacto (Sánchez, 2007), pero se aprecia que la aparición de casos de concordancia ad sensum en el entorno de la misma cláusula con sujeto 'gente' y verbo adyacente es mucho más frecuente en el español malecu (39\%, 52 apariciones de un total de 132 documentadas en un corpus discursivo; ver Sánchez, 2016) que en el español no malecu (7\%, tan solo 3 apariciones de un total de 41). Parece, entonces, que estamos ante un claro ejemplo en el que el español 
malecu ha desarrollado de forma más amplia un fenómeno de variación morfosintáctica ya existente en el español costarricense (y posiblemente general).

Cuadro 2. Concordancia con el sustantivo colectivo 'gente' en el español malecu

\begin{tabular}{|c|c|c|c|c|c|c|c|c|c|c|c|}
\hline & \multicolumn{4}{|c|}{ Margarita } & \multicolumn{3}{|c|}{ Tonjibe } & \multicolumn{3}{|c|}{ El Sol } & \multirow[t]{2}{*}{ Total } \\
\hline & $1 \mathrm{G}$ & $2 \mathrm{G}$ & $3 \mathrm{Ga}$ & $3 \mathrm{~Gb}$ & $1 \mathrm{G}$ & $2 \mathrm{G}$ & $3 \mathrm{G}$ & $1 \mathrm{G}$ & $2 \mathrm{G}$ & $3 \mathrm{G}^{8}$ & \\
\hline $\begin{array}{l}\text { Concordancia } \\
\text { morfológica }\end{array}$ & $\begin{array}{l}15 / \\
79 \%\end{array}$ & $\begin{array}{l}9 / \\
64 \%\end{array}$ & $\begin{array}{l}14 \\
54 \%\end{array}$ & $\begin{array}{l}7 \quad / \\
78 \%\end{array}$ & $\begin{array}{l}12 / \\
60 \%\end{array}$ & $\begin{array}{l}5 \\
56 \%\end{array}$ & $\begin{array}{l}5 \\
83 \%\end{array}$ & $\begin{array}{l}1 / \\
50 \%\end{array}$ & $\begin{array}{l}3 / \\
100 \%\end{array}$ & $\begin{array}{l}9 \quad / \\
37,5 \%\end{array}$ & $\begin{array}{l}80 / \\
61 \%\end{array}$ \\
\hline $\begin{array}{l}\text { Concordancia } \\
\text { ad sensum }\end{array}$ & $\begin{array}{l}41 \\
21 \%\end{array}$ & $\begin{array}{l}5 \quad / \\
36 \%\end{array}$ & $\begin{array}{l}12 / \\
46 \%\end{array}$ & $\begin{array}{l}2 \quad / \\
22 \%\end{array}$ & $\begin{array}{l}8 / \\
40 \%\end{array}$ & $\begin{array}{l}4 / \\
44 \%\end{array}$ & $\begin{array}{l}1 \\
17 \%\end{array}$ & $\begin{array}{l}1 / \\
50 \%\end{array}$ & 0 & $\begin{array}{l}15 \quad / \\
62,5 \%\end{array}$ & $\begin{array}{l}52 / \\
39 \%\end{array}$ \\
\hline
\end{tabular}

La concordancia ad sensum con sustantivos de sentido colectivo exige que el hablante deba decantarse por la concordancia del verbo en singular (ateniéndose a la morfología singular de 'gente') o en plural (ateniéndose a la semántica plural de 'gente'). En el español costarricense sin influjo de otra lengua, la distancia sintáctica entre el sujeto 'gente' y el verbo motiva la concordancia en plural, mientras que la adyacencia sintáctica la restringe (Sánchez, 2007). Lo mismo se ha dicho de otras variedades del español, como la mexicana (Millán, 1977).

En otras variedades del español sin contacto el proceso de concordancia ad sensum ha evolucionado hasta debilitar esta restricción, como se ha descrito para el español hablado por jóvenes en La Habana, según lo informado por Aleza (2011), quien consigna ejemplos como los de 18.. 9 Algunos escasos ejemplos documentados en el español costarricense no malecu (casos en 19.) son de este mismo tipo (Sánchez, 2007).

18. se quedaron poca gente; ahí están más la gente; hay gente que saben menos o saben más

19. eso debían ponerlo en programas de televisión para que la gente se enteren; la gente de allá están viendo a ver cómo desentierran a esa gente

¿Qué ocurre en la gramática del malecu como para que pueda pensarse que la mayor frecuencia del fenómeno en el español malecu esté incentivada por el contacto de lenguas? La noción de 'grupo de personas indeterminado' que se codifica en español mediante el colectivo 'gente' en malecu se codifica como una tercera persona plural, sea mediante el pronombre ní con maráma y un verbo con prefijo de tercera persona (de ergativo o de absolutivo, de acuerdo con la transitividad del verbo) o mediante un verbo conjugado en tercera persona con el marcador maráma sin grupo nominal, como se puede apreciar en 20. y 21.:

20. ní maráma itóye 'la gente se fue';

ní maráma i-tó-ye

este Pl

3Ab-ir-MR

ní maráma rricánhe érra 'la gente come iguana'

ní maráma rri-cánh-e érra

este Pl 3Erg-comer-MR iguana

21. itué maráme 'la gente se fue';

i-tué marám-e

3Ab-ir Pl-MR 
errá rricánh maráme 'la gente come iguana'

errá rri-cánh marám-e

iguana 3Erg-comer Pl-MR

Así las cosas, ante un ámbito de la gramática del español en el cual es común la variación de concordancia singular/plural entre el grupo nominal sujeto y el verbo regido por este dependiendo de si prima el factor morfológico o el semántico, la gramática del malecu promueve la profundización de esta variación en el español hablado por los malecus al interpretar el participante codificado mediante el sustantivo 'gente' como plural. Esta hipótesis nuestra se ve apoyada en el hecho de que la forma plural 'gentes' en el español malecu parece ser más común que en el español costarricense no malecu (de acuerdo con nuestra impresión, pues no existen estudios al respecto), sobre todo en el habla de los adultos (como en 22.) y los jóvenes (como en 23.):

22. allá están las otras gentes en Palenque Tonjibe; gentes de de que adoraban a otros dioses

23. vinieron gentes no indígenas; hay gentes adultas que me hablan en malecu; no hay muchas personas blancas o sea gentes así que estén viviendo en el mismo pueblo; hay gentes en Costa Rica

\subsubsection{La concordancia en verbos de dativo}

Otro tipo de concordancia particularmente llamativo en el español malecu es aquel correspondiente a los verbos de dativo como 'gustarle a uno algo', 'avergonzarle a uno algo' e 'interesarle a uno algo' (llamados así por incluir como argumentos el sujeto y el objeto indirecto, en lugar de sujeto y objeto directo como ocurre regularmente con los verbos que rigen dos argumentos). ${ }^{10}$ En este caso, en el español malecu frecuentemente el verbo se hace concordar con el argumento objeto indirecto (o dativo) y no con el sujeto cuando este es tercera persona plural. ${ }^{11}$ De nuevo, se trata de un fenómeno con vigencia intergeneracional: hemos documentado ejemplos en el habla de ancianos (como en 24.), de adultos (como en 25.) y de jóvenes (como en 26.):

24. a ellas le gustan también [tener amistades]; si le interesan no se va a perder [el malecu a los jóvenes]; mis hijos no le gustan eso; a ellos le daban asco comer no sé qué clase de manteca

25. los jóvenes le dan vergüenza de de que los llamen indios; hay muchos jóvenes que no le gustan / le dan vergüenza; ellas no le gustaron cuando su mamá vino; le interesaban [aprender el malecu a los que llegaban]; ellos le daban risa [por 'a ellos les daba risa']

26. ellos le van a dar miedo [ir a estudiar a San José]; mis hermanillos les gustan molestarlo; hay chiquillos que le gustan participar; hay algunos que no / que ni le interesan ya el hablar; hay muchos que no no le gustan ya el malecu; le dan vergüenza de ser malecu [a muchos jóvenes]; a los turistas le gustaron el mafuriséca [platillo tradional] / le encantaron

Como se puede apreciar, este fenómeno va parejo frecuentemente a la elisión de la marca 'a' introductora de dativo (ejemplos en 27.). De hecho, cuando el verbo de dativo sí se 
hace concordar con el sujeto "normativo" en español, es común que se elida la 'a' del objeto indirecto, lo cual nos parece un paso previo para la reinterpretación de la función sintáctica del argumento dativo:

27. los jóvenes ya no le gusta; eso es lo que el turista le le encanta; la gente como que no le gustaba ir a Tonjibe; ellos le gusta; el malecu le da vergüenza que que le dijeran indio; porque mi mamá no le gustaba hablarnos; ella no le gusta frito; ellos no le gustan también cuando hay rana; mi hermano tampoco le da vergüenza hablar; ellos les encanta

Tanto la frecuente omisión de la preposición 'a' de dativo como la concordancia del verbo con el experimentador muestran que se produce una reinterpretación de la correspondencia entre las funciones sintácticas y la codificación de los participantes. Los verbos de dativo son peculiares en español precisamente por codificar el experimentador como objeto indirecto y no como sujeto, pero en el español malecu se produce un fenómeno de equiparación de estos verbos a la estructura sintáctica de los transitivos.

La elisión de la marca 'a' de objeto indirecto con verbos de dativo se presenta con alguna frecuencia en el español coloquial costarricense, aunque la concordancia verbal no se establece con ese argumento (que codifica el experimentador), como sí ocurre muchas veces en el español malecu, según lo anotado. Aunque hasta el momento no se ha publicado ninguna investigación sistemática acerca de este fenómeno en el español costarricense sin contacto, Ross (1994, p. 224) afirma que frecuentemente el verbo en español no concuerda en número con su sujeto, particularmente en el caso de verbos como 'gustar', 'interesar' y 'preocupar' (es decir, verbos de dativo) con sujetos oracionales, como en 'me preocupó muchas de las cosas que dijo el señor ministro', y sospecha que la falta de animidad del sujeto puede estar detrás del fenómeno.

Se aprecia de nuevo, entonces, que en el español malecu se lleva un paso más allá la variación (y posible cambio linguiístico), tanto en lo que respecta a la omisión de la 'a' introductora del objeto indirecto como a la concordancia en los verbos de dativo. Ambos fenómenos están documentados para el español costarricense, pero no en cuanto a que la concordancia de número se establezca con el argumento que codifica al participante experimentador. Si bien puede ser que sea muy infrecuente, nosotros registramos al menos un ejemplo de una hablante adulta costarricense en un programa televisivo, en el cual el verbo 'doler' concuerda en plural con el argumento 'muchachas' y no con 'la espalda' (caso en 28.). Este ejemplo nos revela que estamos ante un ámbito de la gramática del español susceptible de reestructuraciones.

\section{8. más bien llegan muchachas que le duelen la espalda}

La particular construcción sintáctica del español con los verbos de dativo es terreno fértil para que se produzcan cambios dirigidos a regularizar la interpretación de la función sintáctica de los argumentos; en este caso, la del dativo como sujeto. La RAE (2000, p. 680) aporta algunos indicios acerca de la cercanía entre el sujeto y el complemento indirecto en este tipo de verbos, los cuales, en última instancia, podrían ayudar a motivar la reinterpretación que se registra en el español malecu:

Se ha resaltado en muchas ocasiones que los complementos indirectos de los verbos de afección tienen ciertas propiedades en común con los sujetos. El paralelismo no se basa únicamente en la existencia de pares como Me admira tu valor $\sim$ Admiro tu valor o como lo que me apetece $\sim$ lo que apetezco, sino también en otros aspectos de la sintaxis. Así, por ejemplo, el sujeto 
de la oración principal proporciona en un gran número de casos el antecedente del sujeto

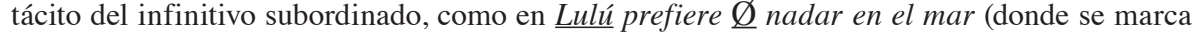
con el signo $\varnothing$ el sujeto tácito del infinitivo y se subrayan los elementos correferentes). Los complementos indirectos de los verbos de afección ejercen ese mismo papel sintáctico, a pesar

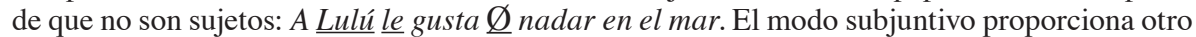
de esos puntos de contacto. En efecto, el sujeto del verbo principal y el del subordinado no son correferentes en oraciones como Norberto desea que regrese. Se obtiene el mismo resultado en A Norberto le agrada que regrese, pero en este caso los elementos que no pueden correferir son el complemento indirecto de la oración principal y el sujeto tácito de la subordinada.

¿Qué papel juega la gramática del malecu en este caso? Dependiendo del verbo y de la construcción sintáctica, el malecu codifica, mediante los prefijos de persona, al participante experimentador en unos casos como ergativo (ejemplo en 29.) y en otros como absolutivo (ejemplo en 30.).

29. tafá rritiú maráme 'a ellos les da miedo el jaguar'

tafá rri-tiú marám-e

jaguar 3Erg-temer Pl-MR

30. cajúlijá pué iptáiqui maráme 'a ellos les gusta el café'

cajúli-já pué i-p-táiqui marám-e

café-sobre bien 3Ab-Ant-sentir Pl-MR

En 29., el experimentador codificado en español como objeto indirecto 'a ellos' corresponde al prefijo de ergativo rri- del malecu, uno de los dos casos nucleares con los que el verbo malecu establece una relación morfosintáctica estrecha (todo verbo transitivo debe llevar un prefijo de ergativo y uno de absolutivo, a menos que aparezca en una construcción gramatical particular, como la antipasiva o la orientación al ergativo, en cuyos casos existen marcas morfológicas que muestran el cambio de construcción; al respecto véase Constenla, 1998). Más literalmente, esta cláusula podría traducirse como 'ellos le temen al jaguar'.

En 30., el experimentador codificado en español como objeto indirecto 'a ellos' corresponde al prefijo de absolutivo $i$ - del malecu, el otro caso nuclear (todo verbo intransitivo debe llevar un prefijo de absolutivo y todo verbo transitivo debe llevar uno de absolutivo más otro de ergativo, salvo en construcciones especiales como las citadas en el párrafo anterior). De hecho, en esta cláusula el verbo táiqui 'sentir' es también transitivo, pero se ha degradado el participante codificado en el argumento ergativo mediante una construcción antipasiva (marcada morfológicamente con el prefijo $p$-) en la cual el participante codificado en el grupo nominal cajúli 'café' se marca como periférico (mediante la posposición enclítica ja lha 'sobre'). Más literalmente, la cláusula podría entonces traducirse en español como 'ellos se sienten bien sobre el café'.

Cuando el participante causante o desencadenante de la emoción o sensación se codifica mediante una cláusula completiva (en cuyo caso el verbo subordinado va en infinitivo con el sufijo - $c a$, pero igualmente se conjuga con los prefijos de persona), también se emplea una construcción antipasiva y el participante experimentador se incluye en el verbo subordinante mediante el prefijo de absolutivo, como ocurre en el ejemplo 31. (mediante el prefijo $i$ - 'tercera persona'), que más literalmente podría traducirse como 'ellos se sienten mal por hablar':

31. corrá iptáiqui maráme ijaíca 'a ellos les da vergüenza hablar' corrá i-p-táiqui marám-e i-jaí-ca mal 3Ab-Ant-sentir Pl-MR 3Ab-hablar-Inf 
En los ejemplos 29., 30. y 31., se puede apreciar que se ha incluido el pluralizador maráma (con la forma maráme por llevar el enclítico de modo real -e) referido al participante experimentador codificado con el prefijo de ergativo o de absolutivo, según el caso. Ciertamente se podría prescindir de este marcador si el contexto o el cotexto ayudan a determinar que se trata de un participante plural y no singular (distinción que, como se recordará, no se indica en el prefijo de persona).

Como vemos, las oraciones del tipo '(a) ellos le(s) dan miedo el jaguar', '(a) ellos le(s) gustan el café' y '(a) ellos le(s) dan vergüenza hablar', relativamente frecuentes en el español de malecus de todas las generaciones (aunque posiblemente más usuales en el habla de los bilingües), muestran que el patrón morfosintáctico del malecu se está replicando en español: el participante experimentador se interpreta como el argumento nuclear de la cláusula y, por lo tanto, el verbo se hace concordar con él.

La frecuente elisión de la 'a' introductora del grupo nominal en función de objeto indirecto en los ejemplos consignados puede analizarse de dos maneras (no excluyentes): como coadyuvante para que la reinterpretación de la función sintáctica (de objeto indirecto a sujeto) tenga lugar (dado que la omisión está documentada en el español no malecu y en el español malecu hemos registrado múltiples elisiones también de 'a' introductora del objeto directo de persona específica) ${ }^{12}$ o como resultado de esta reinterpretación (el grupo nominal se interpreta como sujeto y, por lo tanto, no se introduce con 'a', pues los sujetos en español no llevan esta marca).

Se aprecia, en síntesis, cómo el resultado del cambio lingüístico vinculado a una situación de bilingüismo social puede seguir direcciones divergentes dependiendo de las construcciones. Por un lado, en el español malecu se documentan ejemplos de discordancias -con respecto a la "norma" del español costarricense sin cambios inducidos por contacto- en las que el verbo se conjuga en tercera persona singular con un sujeto de tercera persona plural (y este se codifica mediante un grupo nominal correferencial). Por otro, cuando el sujeto es el sustantivo colectivo 'gente' se registran concordancias ad sensum (es decir, en plural) con mayor frecuencia que en el español no malecu. Finalmente, con los verbos de dativo, se documentan ejemplos de concordancias con el argumento dativo y no con el sujeto, o, dicho de forma más exacta, estamos ante casos de reinterpretación de la función sintáctica que cumple el grupo nominal que codifica el participante experimentador: se considera sujeto y no objeto indirecto, de modo que el verbo se hace concordar con él.

En el fondo, no estamos ante datos contradictorios en absoluto, sino ante un mismo fenómeno de variación en el que eje central consiste en la reorganización del sistema de marcación morfosintáctica de las categorías de persona y número en el verbo. Hemos consignado solo ejemplos en los que la construcción en el español malecu difiere de la construcción en el español no malecu (como ocurre con los verbos de dativo y la neutralización entre el singular y el plural en la conjugación de tercera persona de verbos transitivos e intransitivos) o en los que el mismo fenómeno se presenta en ambas variedades pero con mucha mayor frecuencia en el español malecu (como sucede con la concordancia ad sensum con 'gente').

Sin embargo, en estos tres casos, en el español malecu son más comunes las construcciones coincidentes con el español no malecu (esto es, la interpretación del participante experimentador como objeto indirecto y, por lo tanto, la no concordancia verbal con él, sino con el otro grupo nominal que formalmente funge como sujeto; la concordancia verbal en singular con 'gente'; y la concordancia verbal en plural cuando el sujeto es un grupo nominal en tercera personal plural). Como suele ocurrir con los cambios inducidos por contacto, 
estamos ante fenómenos de variación; es decir, uno o dos patrones morfosintácticos conviven: el innovador (resultado del cambio inducido por contacto) y el conservador (el que se muestra acorde con la "norma" de la variedad sin influjo de la lengua vernácula o el que está sujeto a la presión normativa).

El triunfo de la solución innovadora está sujeto a factores extralingüísticos. En circunstancias desfavorables para que el cambio inducido por contacto se consolide, como ocurre en el caso del español malecu (se trata de una población muy reducida y la variedad de prestigio conservadora se fomenta en la escuela, en los medios de comunicación y en la interacción cotidiana con los hispanos), lo esperable es que este retroceda eventualmente.

En todo caso, entonces, es normal que nos encontremos con ejemplos en los que se neutraliza la categoría de número en el verbo cuando se trata de una tercera persona y que este se conjugue en tercera persona singular, mientras que en otros casos se conjuga el verbo en tercera persona plural con el sujeto 'gente' o cuando se interpreta que el grupo nominal plural que codifica al participante experimentador funge como sujeto y no como objeto indirecto. La gramática del malecu ayuda a que se produzcan tales reinterpretaciones de la relación entre participantes y argumentos formales y, sobre todo, de la concordancia mostrada por el verbo, mediante afijos, con tales argumentos. La variación morfosintáctica ya presente en español no malecu en algunos casos (como la concordancia ad sensum con 'gente') ciertamente constituye tierra fértil para promover el cambio inducido por contacto, pero este tiene lugar también cuando la variación no es común en español, pero sí que se encuentra en potencia (como ocurre con los verbos de dativo).

\subsection{Los argumentos objeto directo y objeto indirecto}

En Sánchez (2015) analizamos pormenorizadamente el reacomodo del sistema de clíticos de objeto directo en el español hablado por los malecus, mediante el examen detallado del mismo corpus discursivo del que provienen muchos de los datos del presente artículo. Postulamos que este se debe a un fenómeno de convergencia estructural inducido por la gramática del malecu, en parangón con reestructuraciones parecidas en el mismo subsistema descritas para otras variedades de español en contacto con una lengua amerindia (Palacios, 2011; 2013).

Esta reestructuración implica que se producen neutralizaciones de género y -en menor cuantía- de número, de manera que se utiliza el archimorfema lo con grupos nominales correferenciales no solo masculinos singulares, sino también femeninos singulares, y masculinos y femeninos plurales, con una clara tendencia a la menor frecuencia del fenómeno conforme se analiza el habla de los sujetos más jóvenes (y con menos competencia en el idioma malecu). Así, documentamos construcciones como 'la esposa sí lo mató una culebra' (por 'a la esposa sí la mató una culebra'), en el habla de un anciano, y 'trajo la película y papi lo está quemando' (por 'trajo la película y papi la está quemando'), en el habla de una niña de diez años (ejemplos ambos no consignados en el artículo en cuestión).

En ese mismo trabajo señalamos que parecía que en el sistema de clíticos de objeto indirecto del español malecu también se podía hallar neutralización de la categoría de número, como se muestra en los ejemplos en 32., fenómeno común en el español costarricense no malecu:

32. ellos no le gusta hablar así en malecu; yo le contaba a ellos; los maestros de cultura le le hacen unas tareas a los chiquitos en malecu; las madres y los padres le hablan a los chiquitos en malecu 
Sin embargo, documentamos también frecuentes neutralizaciones que no se presentan en el español costarricense no malecu, como en los ejemplos en 33. del habla de ancianos y de 34. del habla de jóvenes de Margarita (quienes son los que menos competencia tienen en malecu) y de Tonjibe; en ambos grupos se documentan casos de neutralización máxima:

33. ahi estaba dando clase y me preguntan los chiquillos / “y quién es usted?” / le digo "yo soy malecu” / "no/ usted no es malecu” me dice / "ipor qué?” le digo / "es que yo soy malecu” le digo / y me dicen que en malecu me dice que adónde / que adónde yo vivo / y le pregunto / y le contesto en malecu / "nicó napúca [aquí vivo]" este palenque / Margarita"; "le digo / "ahora otra cosa" le digo / "ustedes quieren hablar el inglés / no es porque le guste / ustedes lo hacen / por necesidad" le digo / "como una fuente de trabajo" / le digo "y lo menos que ustedes / que ustedes no tienen conocimiento"; "cuando yo estuve en la casa de mi hermano / con mis sobrinos / eh: yo le hablaba / pero / no le llama la atención / no le llama la atención / ahora / después de eso / porque le ponen totalmente obligatoriamente le ponen / una tarea / entonces ahí si me consulta o le dicen al papá / y la mamá / entonces este eh / cuando puedo yo le digo este / lo he intentado / de / hablar / pero no quieren / este eh: o sea en otras palabras / no le interesa

34. ellos hablan rápido / en cambio ya uno no / o sea uno uno joven ya a uno joven le hablan despacito ¿verdad? / uno le entiende / pero ellos hablan rápido / como en inglés / en inglés le dicen a uno a veces unas palabras despacio y uno le entiende I ya después se ponen hablar rápido uno no le entiende nada; a ellas le hablaban más I en cambio a mí a mí me hablaban pero yo ya yo no le entendía mucho"; "ustedes son los primeros en morirse" le dije yo / y se pusieron a a enojarse / "mire / que eso nunca va a pasar aquí" / que no sé qué / le digo "sí" / le digo "eso va a pasar algún día” / le digo "en un tiempo no va a existir nada” / le digo "¿quiénes son los primeros en morirse?" / "ustedes / ¿por qué? / porque no comen yuca, que porque no comen pescado / que porque no comen el otro" / le digo "es más” / le digo "y esas palabras que ustedes me están diciendo ahorita / algún día lo van a llegar ustedes mismos a consumir"

El empleo del clítico 'le' en singular con un correferente discursivo plural cercano en el español costarricense sin influjo de una lengua amerindia aparece ya en documentos coloniales de 1673, 1793 y 1794 (Quesada, 1990) y se reporta en el habla contemporánea en Agüero (2009) y en Quesada (2009). En Sánchez (2008) se lleva a cabo un análisis detallado de esta neutralización, de modo que podemos comparar en qué medida el español malecu revela un estadio más avanzado del proceso de cambio lingüístico, como sugerimos en Sánchez (2015).

En Sánchez (2008) se muestra cómo la neutralización de número ocurre en el 12\% de los casos de un corpus de español oral costarricense conformado por 202 clíticos contabilizados y en solamente dos contextos sintácticos: con un grupo nominal correferencial catafórico cercano y con un grupo nominal correferencial anafórico distante. Al respecto se concluye:

En la gran mayoría de los casos, el pronombre 'le' es redundante en cuanto a la clarificación de la referencia textual, pues acompaña al respectivo grupo nominal que establece la identidad del referente explícitamente; así, se convierte en un mero requisito gramatical, sin un papel relevante en la identificación de cualidades informativamente importantes acerca de las entidades discursivas (por ejemplo, la cantidad, codificada gramaticalmente en español en la categoría de 'singular' frente a la de 'plural'). Por lo tanto, el 
pronombre 'le/les' no se comporta en estos casos como una marca de cohesión necesaria para la correcta decodificación del texto, pues la identidad del referente se aclara en el respectivo grupo nominal, que se encuentra muy cerca. La posible ambigüedad en la identificación del referente textual queda anulada en el tanto la cercanía del grupo nominal correferencial implica que haya pocas entidades discursivas en competencia para llenar de contenido el clítico. (Sánchez, 2008, pp. 119-120)

Por el contrario, cuando el clítico sí cumple con su función discursiva de ayudar a recuperar y mantener clara la referencia discursiva (esto es, cuando su grupo nominal correferencial aparece muy distante), aparece la forma no neutralizada 'les'. Así, en el siguiente ejemplo, el archimorfema 'le' sin concordancia coaparece con el grupo nominal 'a los hijos', pero luego el referente discursivo plural se mantiene activo en el discurso por medio del clítico 'les':

34. ya ahora uno le compra a los hijos de eso y como que no les hace gracia, verdad. Bueno el primer día andan así, juegan así, pero después como que les...les aburre, verdad. Claro que eso también se debe a la televisión, a la radio, que les ha ampliado también el panorama

Se aprecia, entonces, que el español malecu lleva un paso más adelante un cambio en proceso en el español costarricense (y común en otras variedades del español hispanoamericano, como se puede ver en DeMello, 1997). ¿Cómo puede incentivar la gramática del malecu este cambio? Así como el sistema de clíticos de persona en el idioma malecu no codifica la categoría de número, del mismo modo tampoco codifica ninguna distinción de género. ${ }^{13}$ Ello explica que, como proponemos en Sánchez (2015), al no estar gramaticalizadas estas nociones en el sistema de prefijos del malecu, el contacto entre ambas gramáticas promueve su neutralización en el español malecu.

Por su parte, en los clíticos de objeto indirecto se neutraliza la categoría de número a favor de un archimorfema le, ya no solo cuando el grupo nominal correferencial se encuentra próximo (y se comporta como un mero requisito gramatical formal) como ocurre en el español costarricense no malecu, sino también cuando este sí cumple la función de recuperar o mantener activa la referencia discursiva (en cuyo caso, en el español costarricense no malecu, no se verifica la neutralización).

En cuanto al objeto indirecto, en el español malecu se encuentra otro fenómeno particular: la introducción del grupo nominal con la preposición 'para', estrategia formal cuya frecuencia de aparición disminuye en los hablantes jóvenes con escasa competencia productiva en malecu. En 35. se consignan ejemplos del habla de personas ancianas de los tres poblados, en 36. del habla de adultos, y en 37. del habla exclusivamente de jóvenes bilingüies de Tonjibe:

35. ¿cómo yo voy a me- mentir para usted que yo soy gente blanca?; yo habla siempre para ellos; su finca lo venden para otro; el maestro está dando clase para los güilas; yo le estaba contando así en malecu para ella; va a darle agua para bestia; cuéntele usted para él; Marta ya no habla para Lucía; a todos le di consejos para ellos; yo estoy orando para Dios; cuida el bebé para ella; si yo hubiera robado algo para esa gente

36. ¿y usted no regala adornitos para otra gente?; mi mamá dijo para un montón de gente; lléveselo para Marta [el bebé]

37. ellos piensan que uno lo va a vender para los turistas; ella lo vendió para otra compañera; no entregó la llave para Marta 
Los objetos indirectos en español general se introducen obligatoriamente con la preposición 'a' (excepto en los casos de omisión ya comentados), pero existe a veces vacilación en lo que respecta a la posibilidad de introducir con la preposición 'para' el grupo nominal que codifica algunos de los participantes normalmente codificados como objetos indirectos en español.

Gutiérrez (2000, p. 1868) indica que tanto el objeto indirecto como la frase preposicional con 'para' pueden servir para codificar participantes beneficiarios en español, del tipo 'compró una chaqueta a Juan/para Juan', 'hizo unos guantes a Laura/para Laura', 'envió unas medicinas a su hijo/para su hijo'. Por su parte, el valor de finalidad solo puede introducirse con 'para' ('ella trabaja para sus hijos'), mientras que los valores de origen, interés y posesión solo se introducen con 'a' ('le puse la cobija a la cama', 'le pregunté la dirección al taxista', 'le rasqué el lomo al gatito'). Habría que agregar que tampoco el participante experimentador se puede codificar con 'para' ('a mí me interesa la historia'). Asimismo, Gutiérrez también señala que algunos verbos no siempre aceptan la alternancia de ambas preposiciones para codificar el participante benefactivo, como el ejemplo consignado por él: 'la ley prohíbe el uso de drogas a los ciudadanos'.

No obstante, en cuanto a los casos de posible alternancia, nótese que en los ejemplos anteriores no aparece el clítico 'le', pues su inclusión inmediatamente llevaría a que se interprete la existencia de dos participantes distintos no correferenciales (uno codificado como objeto indirecto con 'le' y otro codificado con la frase preposicional con 'para'), como en el ejemplo 'le compró un regalo para su nieto'. Por el contrario, si el clítico 'le' aparece con un grupo nominal introducido con 'a' (es decir, con un verdadero objeto indirecto), se interpreta como una duplicación, dado que ambos son correferenciales: 'le compró un regalo a su nieto'. En los ejemplos consignados de español malecu, se puede apreciar que en muchos casos aparece el clítico 'le' y la frase preposicional con 'para' codificando un mismo participante (esto es, son correferenciales), fenómeno no documentado para el español no malecu.

En suma, no hemos de perder de vista que el objeto indirecto (o dativo) constituye en español el argumento sintáctico en el que se pueden codificar varios roles semánticos (destinatarios, receptores, experimentadores) y que también existe la posibilidad de codificar algunas de estas nociones mediante un grupo nominal con 'para'. Es decir, estamos ante una parcela de la gramática del español con cierto grado de variación y al menos dos posibilidades formales de codificación de los participantes receptores y destinatarios (benefactivos o beneficiarios): con un grupo nominal introducido con 'a' (esto es, mediante el argumento objeto indirecto) o con una frase preposicional introducida con 'para' (es decir, mediante un construcción de finalidad).

En la lengua malecu se expresa el dativo mediante un grupo nominal regido por la posposición ajá (y sus alomorfos nhá y ja). De acuerdo con Constenla (1998, p. 106), esta posposición “introduce la persona afectada indirectamente o la finalidad de una acción”. Esto es, la misma posposición sirve en la lengua para codificar tanto los participantes benefactivos como la noción de finalidad, como en los ejemplos consignados por él: nanhá tióca rritáye 'me dio ropa' y níni imlacá ajá 'esto es para que él coma'. Veamos ejemplos de un participante destinatario (en 38. y 39.) y un participante receptor de un evento verbal (en 40. y 41.) codificados como argumento dativo mediante un grupo nominal introducido con ajá en malecu:

38. ijá rratáye púpa 'yo le di una jícara a ella'

i-já rra-tá-ye púpa

3Ab-Dat 1Erg-dar-MR jícara 
39. ijá arrácárre púpa 'yo le compré una jícara a ella'

i-já a-rrá-cárr-e púpa

3Ab-Dat 3Ab-1Erg-comprar-MR jícara

40. ijá arrájuíye póra 'yo le dije un hechizo a ella'

i-já a-rrá-juí-ye póra

3Ab-Dat 3Ab-1Erg-decir-MR hechizo

41. tócujá najáinhe 'yo le recé a Dios'

tócu-já na-jáinh-e

dios-Dat 1Ab-hablar-MR

Dado que los participantes nucleares del evento (agente, paciente, experimentador) se codifican mediante los prefijos verbales de ergativo y absolutivo y los participantes ligados comúnmente al dativo (receptor, beneficiario) son tratados en la lengua como argumentos periféricos en términos sintácticos (como adjuntos posposicionales, sin que exista un prefijo o clítico verbal que los codifique), se entiende que se produzca la reinterpretación de las funciones de 'para' en español malecu: con esta preposición se pueden codificar participantes destinatarios/beneficiarios como en 'por eso el maestro está dando clase para los güilas', 'su finca lo venden para otro' o 'va a darle agua para bestia'; experimentadores como en 'para ellos no no le importa eso' o 'para ellos les cuesta'; y receptores en una cláusula verbal como en 'mentir para usted', 'yo siempre hablo para mis hijos', 'mi mamá dijo para un montón de gente' y 'cuéntele usted para él'.

\section{Conclusiones}

Si bien puede aducirse que otros fenómenos morfosintácticos en el español hablado por los malecus constituyen variaciones y cambios inducidos por el contacto prolongado e intenso entre la lengua malecu y el español (a saber, por ejemplo, la marcación de la evidencialidad en las narraciones con 'dice/dicen', la neutralización de las categorías de género y número en los clíticos de objeto directo, el empleo de la preposición 'en' como introductora de la noción de dirección o destino, y la confluencia de formas de voseo y de ustedeo en una misma cláusula; ver Sánchez (2015; 2016), en los párrafos anteriores nos concentramos en un ámbito de la relación entre la gramática y la semántica en la cual se pueden hallar varios de estos fenómenos: la codificación formal de los participantes mediante la concordancia verbal, los grupos nominales y los clíticos de persona. Nos ha parecido que todos ellos se explican por la reinterpretación de los argumentos de la cláusula en relación con los participantes del evento y los consecuentes cambios en las propiedades formales de codificación.

Dado que las variaciones analizadas no se han documentado para ninguna variedad del español costarricense sin influjo de una lengua indoamericana o se han descrito en un estadio de avance menor del cambio, hay que sospechar que se trata de fenómenos inducidos por contacto, sobre todo porque puede explicarse cómo la gramática del idioma malecu actúa muy probablemente como detonante y refuerzo del proceso de cambio. El procedimiento descriptivo seguido (consignación de ejemplos de un fenómeno no esporádico ni idiolectal, examen de la variación en el español sin influjo reciente de una lengua de contacto, análisis del comportamiento morfosintáctico de la lengua malecu) nos ha permitido argumentar a favor de la tesis del cambio inducido por el factor externo más evidentemente implicado: el contacto de lenguas. 


\section{Notas}

1. Como señalamos en Sánchez (2011) en cuanto a los perfiles sociolingüísticos por grupos generacionales, la terminología concerniente a los tipos de bilingüismo que empleamos describe de manera aproximada el momento de adquisición (bilingüismo sucesivo y bilingüismo simultáneo) y la competencia lingüística (bilingüismo equilibrado y bilingüismo subordinado con el malecu o el español como lengua dominante), según lo reportado por los individuos.

2. Algunos fenómenos, no obstante, se prestan, por su alta aparición en el corpus discursivo, para llevar a cabo cuantificaciones, como sucede con los clíticos de objeto directo (Sánchez, 2015). Cuando ello no es así, nos ha parecido mejor optar por una cuantificación cualitativa (del tipo, 'es frecuente', 'es común en X grupo', 'en X grupo casi no se da', etc.)

3. En el funcionalismo sistémico de Halliday (2004), los tipos de participantes se describen directamente en relación con tipos de cláusulas (determinadas estas, a su vez, por los tipos de procesos). Así, en una cláusula material (aquella en la que se hace o pasa algo en el mundo exterior al hablante) se encuentran participantes distintos a los que se hallan en una cláusula mental (relativa al mundo interior del hablante, como las sensaciones, emociones y pensamientos). Por su parte, en el funcionalismo tipológico representado por Givón (2001), es común que se proponga una tipología básica de roles semánticos con independencia de los tipos de cláusulas.

4. En realidad Givón (2001) distingue entre las propiedades de codificación manifiestas (“overt”), como las citadas, y las propiedades de control y comportamiento, relativas a diversas construcciones sintácticas regidas por el sujeto o el objeto directo, como la pasivización, la reflexivización, la relativización, etc. Como la segunda categoría no es pertinente para nuestros propósitos, únicamente aludimos al primer tipo.

5. Le agradezco al Dr. Ronald Ross el haberme recordado este dato.

6. Empleamos las siguientes abreviaturas en la traducción literal de los ejemplos en malecu: 3= tercera persona, $1=$ primera persona, $\mathrm{Ab}=$ absolutivo, $\mathrm{Erg}=$ ergativo, $\mathrm{Pl}=$ plural, $\mathrm{MR}=$ modo real, $\mathrm{Ant}=$ antipasiva, Inf= infinitivo, Dat $=$ dativo.

7. Nótese que hablamos de vínculo formal, debido a que, como puede apreciarse en los ejemplos 11. y 12., no se trata tan solo de que en 11. el marcador de pluralidad se posponga al grupo nominal, mientras que en 12. se pospone al verbo, sino que el enclítico de modo real aparece en 11. ligado a la base verbal (con la forma -ye en itóye o -nhe en irricánhe), mientras que en 12. se une al pluralizador maráma (con la forma - $e$; de ahí que aparezca maráme y no maráma).

8. $1 \mathrm{G}=$ jóvenes, $2 \mathrm{G}=$ adultos, $3 \mathrm{G}=$ ancianos, $3 \mathrm{Ga}=$ ancianos con el malecu como lengua dominante (Margarita), 3Gb=ancianos con bilingüismo equilibrado (Margarita).

9. También Sedano y Bentivoglio (1996, p. 122) registran como frecuente el fenómeno para el español de Venezuela (con el ejemplo 'la gente dicen que va a haber un golpe de estado').

10. Preferimos esta denominación que apunta hacia lo formal y no hacia lo semántico (como la nomenclatura "verbos de afección" o "verbos psicológicos" empleada por la RAE, 2010) por el problema que implica subsumir en un mismo tipo semántico todos los valores codificados en estos verbos. En efecto, la categoría de verbos de dativo no solo incluye los verbos de afección, sino que también puede incluir los denominados por la RAE (2010) "verbos de acaecimiento" ('ocurrir' y 'pasar'), "verbos de atingencia o pertinencia" ('importar' o 'incumbir'), "verbos de daño o provecho” ('convenir'), los de “necesidad, adecuación o suficiencia” ('bastar' y 'faltar'), los de "pertenencia” ('pertenecer'), los de “utilidad” ('servir'), e incluso otros de difícil etiquetación como 'quedar' referido a prendas de vestir, 'costar' (como en 'me cuesta el análisis sintáctico') y ‘dar' en múltiples construcciones (como ‘dar vergüenza' y ‘dar cólera').

11. Rodríguez (2008, p. 152) informa del mismo fenómeno, aunque solo con el verbo 'gustar', en el español hablado por los ika de Colombia: "el uso del verbo gustar con un sujeto concordante: Loh indígena no le guhtan/ ehte hablar cuando ehtá lo otro porque ('A los indígenas no les gusta hablar, este hablar...'). Nótese en este ejemplo la ausencia de la preposición 'a', la concordancia en el número del verbo gustar con la frase nominal en función de sujeto gramatical los indígenas."

12. Algunos ejemplos de omisión de 'a' ante grupos nominales que cumplen la función de objetos indirectos de verbos ditransitivos y de objetos directos de persona específica con verbos transitivos son: 'yo le dije aquí la gente', 'una que que que supervisa los indígenas', 'yo le he dicho mucho mis hijos', 'yo no conocí 
mi abuela', 'estos malecus les decían los indios', 'ella le contaban digamos historias', 'porque ella la molestan y se enoja rápido'.

13. De hecho, la categoría extralingüística de 'sexo biológico' solo está lexicalizada en malecu en unos pocos casos, todos ellos referidos a humanos (como la distinción entre ochápacá 'hombre' y curíjurí 'mujer', y las relaciones de parentesco).

\section{Bibliografía}

Agüero, A. (2009). El español de Costa Rica. San José: Editorial de la Universidad de Costa Rica.

Aleza, M. (2011). Fenómenos gramaticales en el habla culta de la generación joven de La Habana, Cuba. Materiales para su estudio. Itinerarios. 13, 29-51.

Alvar, M. (Ed.). (1996). Manual de dialectología hispánica. El español de América. Barcelona: Ariel Lingüística.

Arroyo, V. (1971). El habla popular en la literatura costarricense. San José: Publicaciones de la Universidad de Costa Rica.

Bosque, I. y Demonte, V. (Eds.). (2000). Gramática Descriptiva de la Lengua Española. Madrid: Espasa Calpe.

Conde, J. (2007). Sociolingüística histórica. Madrid: Gredos.

Constenla, A. (1975). La lengua guatusa: fonología, gramática y léxico. (Tesis de Licenciatura). Universidad de Costa Rica.

Constenla, A. (1988). El guatuso de Palenque Margarita: Su proceso de declinación. Estudios de Lingüística Chibcha. 7, 7-37.

Constenla, A. (1998). Gramática de la lengua guatusa. Heredia: Editorial de la Universidad Nacional de Costa Rica.

Constenla, A. (2005). Algunos aspectos lingüísticos y socioculturales de la influencia de las lenguas indígenas en las variedades americanas del español. Boletín de la Academia Costarricense de la Lengua. 1, 65-86.

Croft, W. (1990). Typology and Universals. Cambridge: Cambridge University Press.

DeMello, G. (1997). Le por les. Por J. De Kock y G. DeMello (Eds.). Lengua escrita y habla culta en América y España. Diez casos. (53-66). Salamanca: Ediciones Universidad de Salamanca.

De Kock, J. y DeMello, G. (Eds.). (1997). Lengua escrita y habla culta en América y España. Diez casos. Salamanca: Ediciones Universidad de Salamanca.

Givón, T. (2001). Syntax. Amsterdam: John Benjamins Publishing Company.

Gutiérrez, S. (2000). Los dativos. Por I. Bosque y V. Demonte (Eds.). Gramática Descriptiva de la Lengua Española. (1855-1930). Madrid: Espasa Calpe.

Halliday, M. (2004). An Introduction to Functional Grammar. Londres: Hodder Arnold.

Jara, C. (2008). La concordancia pragmática del verbo en español. Káñina. 32 (2), 57-68.

Krohn, H. (2012). El mantenimiento de la referencia anafórica en el discurso tradicional en lengua malecu. Revista de Filología y Lingüística. 38 (1), 191-216. 
Léglise, I. y Chamoreau, C. (Eds.). (2013). The Interplay of Variation and Change in Contact Settings. Amsterdam: John Benjamins Publishing Company.

Lope, J. (Ed.). (1977). Estudios sobre el español hablado en las principales ciudades de América. México: Universidad Nacional Autónoma de México.

Matras, Y. (2009). Language Contact. Cambridge: Cambridge University Press.

Millán, A. (1977). Anomalías en la concordancia del nombre en el español de la Ciudad de México. Por Lope, J. (Ed.). Estudios sobre el español hablado en las principales ciudades de América. (85-104). México: Universidad Nacional Autónoma de México.

Palacios, A. (Ed.). (2008). El español en América. Contactos lingüísticos en Hispanoamérica. Barcelona: Ariel.

Palacios, A. (2008). Introducción. Por A. Palacios (Ed.). El español en América. Contactos lingüísticos en Hispanoamérica. (11-15). Ariel: Barcelona.

Palacios, A. (2011). Nuevas perspectivas en el estudio del cambio inducido por contacto: Hacia un modelo dinámico del contacto de lenguas. Lenguas Modernas. 38, 17-36.

Palacios, A. (2013). Contact-induced change and internal evolution. Spanish in contact with Amerindian languages. Por I. Léglise y C. Chamoreau (Eds.). The Interplay of Variation and Change in Contact Settings. (165-198). Amsterdam: John Benjamins Publishing Company.

Quesada, M. (1990). El español colonial de Costa Rica. San José: Editorial de la Universidad de Costa Rica.

Quesada, M. (1991). El español de Guanacaste. San José: Editorial de la Universidad de Costa Rica.

Quesada, M. (2009). Historia de la lengua española en Costa Rica. Sán José: Editorial de la Universidad de Costa Rica.

Quesada, M. (2010). Atlas lingüístico-etnográfico de Costa Rica (ALECORI). San José: Editorial de la Universidad de Costa Rica.

RAE (Real Academia Española de la Lengua). (2010). Nueva gramática de la lengua española. Manual. México: Editorial Planeta.

Rodríguez, Y. (2008). Colombia. Por A. Palacios (Ed.). El español en América. Contactos lingüísticos en Hispanoamérica. (135-160). Ariel: Barcelona.

Ross, R. (1994). La animidad en la gramática del español. Por Y. Solano (Comp.). Memoria del $V$ Congreso de Filología y Lingüística Arturo Agüero Chaves. (220-225). San José: Editorial Guayacán.

Sánchez, C. (2007). "Para que la gente se enteren”. La concordancia ad sensum en español oral. Revista de Filología y Lingüística. 33 (2), 205-226.

Sánchez, C. (2008). El uso de 'le’ por 'les' en el español costarricense: de la cohesión a la morfologización. Revista Internacional de Lingüística Iberoamericana. 6 (1), 111-127.

Sánchez, C. (2011). Caracterización cualitativa de la situación sociolingüística del pueblo malecu. Estudios de Lingüística Chibcha. 30, 63-90. 
Sánchez, C. (2015). El sistema pronominal átono de tercera persona en el español hablado por los malecus de Costa Rica. Círculo de Lingüística Aplicada a la Comunicación. 61, 79-103.

Sánchez, C. (2016). El español hablado por los malecus: Caracterización general y reconocimiento como variedad particular. Káñina. 40 (1), 103-125.

Sedano, M. y Bentivoglio, P. (1996). Venezuela. Por M. Alvar (Ed.). Manual de dialectología hispánica. El español de América. (116-133). Barcelona: Ariel.

Solano, Y. (Comp.). (1994). Memoria del V Congreso de Filología y Lingüística Arturo Agüero Chaves. San José: Editorial Guayacán.

Thomason, S. (2001). 2001. Language Contact: An Introduction. Edinburgh: Edinburgh University Press. 
